\title{
The enduring problem of 'grey' drone violence
}

\author{
Christian Enemark* \\ School of Economic, Social and Political Sciences, University of Southampton, Southampton, United Kingdom \\ ${ }^{\star}$ Corresponding author. Email: c.enemark@soton.ac.uk
}

(Received 22 April 2021; revised 31 August 2021; accepted 8 October 2021; first published online 4 November 2021)

\begin{abstract}
This article addresses the problem of drone violence that is 'grey' in the sense of being hard to categorise. It focuses on circumstances, such as arose in Pakistan, in which a foreign government's armed drones are a constant presence. A lesson from US experience there is that the persistent threat of drone strikes is intended to suppress activities that endanger the drone-using state's security. However, this threat inevitably affects innocent people living within potential strike zones. To judge such drone use by reference to military ethics principles is to assume that 'war' is going on, but indefinite drone deployments are difficult to conceptualise as war, so traditional Just War thinking does not suffice as a basis for moral judgement. In assessing the US government's commitment to drone-based containment of risks emerging along its 'terror frontier', the article considers three alternative conceptualisations of drone violence arising in non-war contexts: vim ('force short of war'), terrorism, and imperialism. It then rejects all three and proposes that such violence is better conceptualised as being merely 'quasi-imperialistic'. On this basis, however, the sustaining of a drone strike campaign against a series of suspected terrorists can still be condemned as violating the right to life.
\end{abstract}

\section{Introduction}

On 20 January 2021, the day of Joe Biden's inauguration as President of the United States, the incoming national security adviser issued an order for tighter controls on counterterrorism operations outside war zones (away from where there are US troops present). Under the Trump administration, military commanders and the Central Intelligence Agency (CIA) had reportedly been allowed to decide for themselves when to conduct drone strikes against suspected terrorists. Henceforth, by contrast, permission for such attacks needed first to be obtained from the White House, pending an internal review of policy and procedures. ${ }^{1}$ These largely secret 'rules' on US drones strikes, originally formulated during Barack Obama's presidency, formed part of an ongoing attempt by the US government to control and legitimise a largely unprecedented form of extraterritorial state violence.

In continuing the covert use of armed drones outside war zones, successive US administrations have apparently been unwilling or unable to assign this activity to either of the two existing paradigms for legitimately using force - war and law enforcement - wherein there is a ready supply of internationally agreed rules. Rather, the US government has seemed content to convey the idea that some of its drone violence is essentially neither warfare nor policing and thus beyond the ordinary sanction of humanitarian and human rights law. However, the vagueness of this conceptualisation - the contrived 'greyness' of such violence - has generated a concern about

\footnotetext{
${ }^{1}$ Charlie Savage and Eric Schmitt, 'Biden quietly limits drone strikes away from war zones', New York Times (4 March 2021), p. A12.

(c) The Author(s), 2021. Published by Cambridge University Press on behalf of the British International Studies Association. This is an Open Access article, distributed under the terms of the Creative Commons Attribution licence (https://creativecommons.org/licenses/by/4.0/), which permits unrestricted re-use, distribution, and reproduction in any medium, provided the original work is properly cited.
} 
state impunity: that injustices caused by drone-based campaigns against suspected terrorists might escape notice and remedy. Amnesty International has argued, for example, that US policy and practice sets 'a dangerous precedent' for other drone-using states to 'avoid responsibility' for potentially unlawful killings. ${ }^{2}$

For drone strikes occurring outside areas of armed conflict to be properly judged and governed, an important first step is to arrive at a plausible conceptualisation of such violence. Accordingly, this article sets out to assess the nature and morality of US drone campaigns along America's 'terror frontier', which include the recent experience of CIA operations in the Federally Administered Tribal Areas (FATA) of northwestern Pakistan. Here, for many years, drone violence was directed against a series of suspected terrorists identified according to behavioural signatures deemed to indicate threats to US security. Although CIA 'signature strikes' in FATA appeared to have ceased at the time of writing, this form of violence remains worthy of consideration because of its potential to recur, not least because the number of states using armed drones has lately been increasing. ${ }^{3}$

Several authors have already sought to engage with the moral problem of 'grey' drone violence by offering conceptualisations beyond 'war' or 'law enforcement'. One suggestion has been to conceptualise some drone strikes as a form of vim ('force short of war') and to govern such force according to a jus ad vim framework adapted from Just War theory. ${ }^{4}$ Another approach has been to condemn US drone strikes outside war zones, in a way that combines conceptualisation with adverse judgement. According to some authors taking this approach, who emphasise the harmful effects of drone use upon innocents in the vicinity of strikes, this is essentially terroristic violence. ${ }^{5}$ And other authors, focusing on US foreign policy and behaviour in the world, have argued that drone violence against suspected terrorists is imperialistic in nature. ${ }^{6}$

All three conceptualisations are assessed in later sections, but vim, terrorism, and imperialism are ultimately rejected as unhelpful or inaccurate. Instead, this article proposes a conceptual reorientation, introducing the idea that the US use of armed drones in non-war circumstances (for example, in FATA) is 'quasi-imperialistic' violence. In essence, drone violence of this kind is wielded in the pursuit only of thin domination, and without taking responsibility for the welfare of the dominated, and as such it functions merely as an instrument for policing emergent terrorist risks. Even so, and because of these features, quasi-imperialistic drone violence is open to condemnation as a violation of the human right to life.

\section{The problem of 'grey' drone violence}

When the US government uses armed drones in places where there are conflicts going on (Afghanistan, Iraq, Libya, and Syria), these aircraft are among numerous tools used together in a wider military effort. Drone-launched missile strikes are often used to provide close air support in defence of friendly troops who are in contact with or otherwise threatened by enemy troops. Here, the conceptualising of drone violence is generally not a problem. It is the violence of war,

\footnotetext{
${ }^{2}$ Amnesty International, 'Will I Be Next': US Drone Strikes in Pakistan (London, UK: Amnesty International Publications, 2013), p. 56.

${ }^{3}$ Drone Wars, 'Who has Armed Drones?' (July 2021), available at: \{https://dronewars.net/who-has-armed-drones/\} accessed 27 August 2021.

${ }^{4}$ See John Emery and Daniel R. Brunstetter, 'Restricting the preventive use of force: Drones, the struggle against non-state actors, and jus ad vim', in Kerstin Fisk and Jennifer M. Ramos (eds), Preventive Force: Drones, Targeted Killing, and the Transformation of Contemporary Warfare (New York, NY: New York University Press, 2016), pp. 257-82.

${ }^{5}$ See Laurie Calhoun, 'Totalitarian tendencies in drone strikes by states', Critical Studies on Terrorism, 11:2 (2018), pp. 35775; Ian G. R. Shaw, Predator Empire: Drone Warfare and Full Spectrum Dominance (Minneapolis, MN and London, UK: University of Minnesota Press, 2016), p. 136.

${ }^{6}$ See Majed Akhter, 'The proliferation of peripheries: Militarized drones and the reconfiguration of global space', Progress in Human Geography, 43:1 (2019), pp. 64-80; Timothy Vasko, 'Solemn geographies of human limits: Drones and the neocolonial administration of life and death', Affinities: A Journal of Radical Theory, Culture, and Action, 6:1 (2013), pp. 83-107.
} 
and war is generally understood to be one of two established paradigms for legitimate state violence. The other paradigm is law enforcement. Armed drones could one day be used for a domestic policing purpose (although no police department anywhere appears yet to have done so), or they could be used to punish criminal wrongdoing. For each of these paradigms, a set of principles and laws is available to be applied in determining whether an instance of state violence is just or unjust. There is human rights law, which mainly applies in peacetime (for example, to criminal justice matters) and severely restricts killing, and there is humanitarian law, which applies in wartime and is more permissive.

Sometimes, however, armed drones are used in non-war circumstances and without obviously serving a policing or punitive purpose. Here, on the one hand, a concern arises that drone violence appears to lack any potential for legitimacy and thus amounts to impermissible homicide in violation of the right to life. On the other hand, as the US government has claimed, it raises the possibility that such violence can be legitimate despite being neither war nor law enforcement. To assess these rival propositions, this article focuses on the maintaining of drone programmes that involve the conduct of signature strikes in a foreign territory. Also known as 'terrorist attack disruption strikes, ${ }^{7}$ these are a 'grey' form of drone violence in the sense of being uncategorised or conceptually uncertain.

US signature strikes, unlike 'personality strikes' against named individuals, are conducted and justified based on pattern-of-life analysis of information about people and places collected from various sources. This analysis is undertaken to spot patterns that match one or more signature activities deemed to be indicative of a terrorist threat. Examples of suspicious activities, gleaned from public statements by US government officials, include 'planning attacks', 'transporting weapons', 'handling explosives', and 'consorting with known militants'. The information used to identify these and other signatures reportedly includes metadata from computers and mobile phones, aerial surveillance footage, and voice patterns of callers, which can be compared to thousands of other stored voice samples linked to suspected terrorists. ${ }^{9}$ Under the Obama administration, as a guide for the conduct of signature strikes, the US government developed not a simple list of names but rather a 'disposition matrix'; a 'single, continually evolving database in which biographies, locations, known associates and affiliated organizations are all catalogued'. ${ }^{10}$

The US government has reportedly conducted signature strikes in at least three territories where it is neither party to an armed conflict nor enforcing the local criminal law: in Yemen, Somalia, and, most of all, in Pakistan's northwestern FATA region (which shares a highly porous border with Afghanistan). In these places, the sustaining of drone violence against a series of suspected terrorists has been intended to achieve a continuously disruptive effect. The apparent rationale is that, by forcing members of 'terrorist groups' inside targeted territories to spend time and resources on trying to avoid detection and stay alive, they have less of an opportunity to recruit, train, organise, and execute attacks against US interests. ${ }^{11}$

Even if signature strikes are thus effective in suppressing perceived threats to the United States, part of the moral difficulty associated with drone violence of this kind is that innocents

\footnotetext{
${ }^{7}$ Greg Miller, 'CIA didn't know strike would hit al-Qaeda leader', Washington Post (17 June 2015), available at: \{https:// www.washingtonpost.com/world/national-security/al-qaedas-leader-in-yemen-killed-in-signature-strike-us-officials-say/ 2015/06/17/9fe6673c-151b-11e5-89f3-61410da94eb1_story.html\} accessed 10 November 2020.

${ }^{8}$ Kevin Jon Heller, 'One hell of a killing machine: Signature strikes and international law', Journal of International Criminal Justice, 11:1 (2013), pp. 89-119 (pp. 94-5, 97).

${ }^{9}$ Dan Gettinger, 'The Disposition Matrix', Center for the Study of the Drone, Bard College (25 April 2015), available at: \{http://dronecenter.bard.edu/the-disposition-matrix/\} accessed 24 March 2021.

${ }^{10}$ Greg Miller, 'Plan for hunting terrorists signals U.S. intends to keep adding names to kill lists', Washington Post (23 October 2012), available at: \{http://articles.washingtonpost.com/2012-10-23/world/35500278_1_drone-campaignobamaadministration-matrix accessed 24 March 2021

${ }^{11}$ Jacqueline L. Hazelton, 'Drone strikes and grand strategy: Toward a political understanding of the uses of unmanned aerial vehicle attacks in US security policy', Journal of Strategic Studies, 40:1-2 (2017), pp. 68-91 (pp. 78-9).
} 
sometimes end up being harmed as well. In mid-2016, the Director of National Intelligence reported that, during the previous seven years, the US government had conducted 473 counterterrorism strikes outside areas of active hostilities. These had resulted in an estimated total of between 2,372 and 2,581 'combatant deaths' and between 64 and 116 'non-combatant deaths'. ${ }^{12}$ There are uncertainties about the accuracy of these numbers and about whom the US government counts as 'combatants' and 'non-combatants' in the first place. However, for present purposes the most interesting feature of this report (and related official pronouncements) is that these categories of victim are used at all. The idea of being either a 'combatant' or a 'non-combatant' arises only in war circumstances, but on its own account the US government has sometimes used armed drones 'outside areas of active hostilities'. ${ }^{13}$

Military ethics and humanitarian law traditionally permit the unintentional and proportional killing of non-combatants when enemy combatants are being targeted, so the US government is possibly making a claim on such permission when it employs some of the language of war in this way. The alternative to be avoided, presumably, is a default to the ethics applicable in the only other established paradigm of legitimate state violence - the peacetime business of law enforcement - where there are no 'combatants' (only people) and there is a stronger presumption against killing. Accordingly, because the US government is unable plausibly to claim it is at war but is unwilling to have its signature strikes judged according to the ethical expectations that obtain in peacetime, it has instead engaged in an expedient 'greying' of this form of drone violence. This has been done in a geographical sense and through legal innovation: by blurring the distinction between zones of war and zones of peace, and by asserting the existence of a category of legitimate state violence ('self-defence targeting') beyond the established categories of war and peacetime law enforcement.

The claimed legitimacy of wielding drone violence neither in war nor for a law enforcement purpose rests in part upon an argument that conditions in certain parts of the world are in between' the conditions of war and peace. In such territories, the argument goes, the law enforcement paradigm (and its associated framework of criminal justice ethics) does not apply in principle because law enforcement cannot in practice be conducted there. That is, some places where armed conflict is not occurring are nevertheless not to be regarded as zones of peace because, against the threat of terrorism, 'law enforcement mechanisms ... are not a viable option'. ${ }^{14}$ The perceived problem, in what Seumas Miller has labelled 'disorderly jurisdictions', is that 'there is no effective law enforcement in relation to terrorists conducting attacks on liberal democratic states'. 15 The discourse accompanying this argument is one of dangerous 'ungoverned spaces', from which terrorist threats to the United States emanate. ${ }^{16}$ These places, as Majed Akhter has observed, are the 'global periphery' towards which armed drones proliferate 'despite the absence of a declared battlefield'. ${ }^{17}$ Indeed, most CIA drone strikes have occurred in Pakistan's FATA, a frontier region historically scripted as 'ungoverned'. ${ }^{18}$

Another way in which the US government has sought to create normative space for its nonwar drone violence has been to engage in legal innovation. In response to accusations that it was

\footnotetext{
${ }^{12}$ Director of National Intelligence, 'Summary of Information Regarding U.S. Counterterrorism Strikes Outside Areas of Active Hostilities', Office of the Director of National Intelligence, US Government (1 July 2016), available at: \{https://www. dni.gov/files/documents/Newsroom/Press\%20Releases/DNI+Release+on+CT+Strikes+Outside+Areas+of+Active+Hostilities. PDF\} (accessed 23 March 2021).

${ }^{13}$ Ibid.

${ }^{14}$ Megan Braun and Daniel R. Brunstetter, 'Rethinking the criterion for assessing CIA-targeted killings: Drones, proportionality and jus ad vim', Journal of Military Ethics, 12:4 (2013), pp. 304-24 (p. 316).

${ }^{15}$ Seumas Miller, Shooting to Kill: The Ethics of Police and Military Use of Lethal Force (New York, NY: Oxford University Press, 2016), p. 265, emphasis added.

${ }^{16}$ Janosch Prinz and Conrad Schetter, 'Conditioned sovereignty: The creation and legitimation of spaces of violence in counterterrorism operations of the "War on Terror", Alternatives: Global, Local, Political, 41:3 (2016), pp. 119-36 (p. 119).

${ }^{17}$ Akhter, 'The proliferation of peripheries', p. 66.

${ }^{18}$ Christine Agius, 'Ordering without bordering: Drones, the unbordering of late modern warfare and ontological insecurity’, Postcolonial Studies, 20:3 (2017), 370-86 (p. 371).
} 
illegally using force in Pakistan, Somalia, and Yemen, the Obama administration moved to reframe humanitarian and human rights law obligations to expand the legal scope for violent action. ${ }^{19}$ Ordinarily, from a legal perspective, 'armed conflict' is limited to situations of intense and organised fighting, and only in such situations is humanitarian law (which is more permissive of killing than is human rights law) applicable. Where there is greater doubt about whether a specific operation counts as armed conflict, the more difficult it is to claim that killing individual terrorist suspects in this context is lawful. ${ }^{20}$ So, to get around this difficulty while targeting suspected terrorists in signature strikes 'outside areas of active hostilities', ${ }^{21}$ the US government has asserted that killings do not need to be justified under human rights law as long as they represent legitimate acts of national self-defence. On this basis, drone violence has been presented not as falling into a legal vacuum between the war and law enforcement paradigms (where no moral and legal basis for killing is available), but rather as an example of a third kind of legitimate state violence: 'self-defence targeting'.

In 2010, US State Department legal adviser Harold Koh argued publicly that ' $\mathrm{n}$ ] ot every resort to force in self-defense by a state is necessarily undertaken through the conduct of armed conflict', and that 'a state that is engaged in an armed conflict or in legitimate self-defense is not required to provide targets with legal process before the state may use lethal force'. ${ }^{22}$ This was an assertion that states can legitimately engage in extraterritorial violence and yet not be engaged in an armed conflict (at least in the legal sense of that term). Six years later, this legal innovation appeared also in an Executive Order issued by President Obama, which stated: 'Civilian casualties are a tragic and at times unavoidable consequence of the use of force in situations of armed conflict $o r$ in the exercise of a state's inherent right of self-defense. ${ }^{23}$ Here, official US reasoning extended to implying that non-combatants ('civilians') can be considered to exist (as a category) even in non-war circumstances (where US troops are not involved in combat).

This attempt at legally inventing a 'grey' version of drone violence (between the black and white bodies of law on war and law enforcement) attracted widespread criticism for its potential to weaken humanitarian and rights-based protections for individuals in international law. ${ }^{24}$ Two months after Koh's speech, Philip Alston (then the UN Special Rapporteur on Extrajudicial, Summary, or Arbitrary Executions) warned, in reference to armed drones, of 'a highly problematic blurring and expansion of the boundaries of the applicable legal frameworks - human rights law, the laws of war, and the law applicable to the use of inter-state force'. ${ }^{25}$ The principal concern here, which still endures, is that emphasising self-defence to justify violence at the inter-state level might enable a bypassing of established legal standards governing violence against individual

\footnotetext{
${ }^{19}$ Rebecca Sanders, 'Legal frontiers: Targeted killing at the borders of war, Journal of Human Rights, 13:4 (2014), pp. 51236 (p. 513).

${ }^{20}$ Christian Schaller, 'Using force against terrorists "outside areas of active hostilities": The Obama approach and the Bin Laden raid revisited', Journal of Conflict \& Security Law, 20:2 (2015), pp. 195-227 (pp. 197-8).

${ }^{21}$ Director of National Intelligence, 'Summary of Information Regarding U.S. Counterterrorism Strikes Outside Areas of Active Hostilities'.

${ }^{22}$ Harold Hongju Koh, 'The Obama Administration and International Law', US Department of State (25 March 2010), available at: \{https://2009-2017.state.gov/s/l/releases/remarks/139119.htm\} accessed 24 March 2021 (emphasis added).

${ }^{23}$ Government Publishing Office, '3 CFR 13732 - Executive Order 13732 of July 1, 2016. United States Policy on Pre- and Post-Strike Measures to Address Civilian Casualties in U.S. Operations Involving the Use of Force', US Government Publishing Office, available at: \{https://www.govinfo.gov/app/details/CFR-2017-title3-vol1/CFR-2017-title3-vol1-eo13732/ summary\} accessed 24 March 2021, emphasis added.

${ }^{24}$ See Laurie R. Blank, 'Targeted strikes: The consequences of blurring the armed conflict and self-defense justifications', William Mitchell Law Review, 38:5 (2012), pp. 1655-700; Max Brookman-Byrne, 'Drone use "outside areas of active hostilities": An examination of the legal paradigms governing US covert remote strikes', Netherlands International Law Review, 64:1 (2017), pp. 3-41.

${ }^{25}$ Philip Alston, 'Report of the Special Rapporteur on Extrajudicial, Summary or Arbitrary Executions. Addendum: Study on Targeted Killings', A/HRC/14/24/Add.6, Human Rights Council United Nations General Assembly, 28 May 2010, para. 3. See also Rosa Brooks, How Everything Became War and the Military Became Everything: Tales from the Pentagon (New York, NY: Simon \& Schuster, 2016).
} 
persons. If this were to happen, the issue of the permissibility of violating a targeted individual's right to life (as a matter of conducting violence) would collapse, leaving only the issue of whether resorting to force in world affairs is permissible.

While ever the US idea of 'self-defence targeting' is unaccepted as an additional category of legitimate state violence, the conduct of non-war drone strikes against suspected terrorists in 'ungoverned' territories is conceptually unsatisfactory. And the related problem of suspected injustice that remains is that unlawful killings might be occurring with impunity. In response to concerns that a drone-using state cannot be held accountable for the consequences of its 'grey' violence, ${ }^{26}$ a promising approach is to give another name to drone violence outside war zones in order to gain some moral and governance traction upon it. Alternatives include conceptualising signature strikes as vim ('force short of war') or terroristic violence, or as imperialistic or quasi-imperialistic violence.

\section{Drone violence as vim}

In response to the US resorting to 'legal ambiguity' to justify some drone violence, one suggestion is to accommodate this by introducing a 'hybrid moral framework'. ${ }^{27}$ This is needed, it is argued, to cover 'limited force that lies somewhere between law enforcement and just war, and combines elements of both'. ${ }^{28}$ If counterterrorist drone strikes were conceptualised as a third category of legitimate state violence - as vim ('force short of war') - they could then be either defended as just vim or condemned as unjust vim. In other words, 'outside the "hot" battlefield', ${ }^{29}$ drone violence could be judged according to a framework of jus ad vim (the justice of resorting to 'force short of war'). Advocates of such a framework are motivated by a concern to see that state violence, which putatively emerges in 'a gray area between law enforcement and war', ${ }^{30}$ does not escape subjection to ethical judgement and principled regulation. Assuming that this greyness is real (rather than merely a government's self-interested assertion), the purported advantage of conceptualising 'grey' drone violence as vim is to gain more moral leverage and bring about greater restraint of it than has thus far been achieved.

For example, the labelling of some kinds of drone strikes as vim (non-war) rather than bellum (war) would bring into play a more restrictive ethics - jus in vi (the justice of conducting 'force short of war') - which is more protective of civilians than is jus in bello (incorporating the military ethics principles of necessity, discrimination, and proportionality). Accordingly, even the unintended killing of civilians could be entirely proscribed by a jus in vi requirement of 'zero incidental civilian harm'. ${ }^{31}$ Or, as Shannon Ford has suggested, 'foreseeable collateral [civilian] deaths' could be 'either not permissible or equivalent to what we would be willing to accept in a standard [domestic] policing operation'. ${ }^{32}$

Nevertheless, according to its critics, the idea of a jus ad vim framework might yet be undesirable or unnecessary. One policy argument against introducing a third (hybrid) paradigm of legitimate state violence is that this would weaken the theoretical protections enjoyed by civilians and

\footnotetext{
${ }^{26}$ Scott H. Englund, 'A dangerous middle-ground: Terrorists, counter-terrorists, and gray-zone conflict', Global Affairs, 5:4-5 (2019), pp. 389-404 (p. 391).

${ }^{27}$ Emery and Brunstetter, 'Restricting the preventive use of force', p. 258; S. Brandt Ford, 'Jus ad vim and the just use of lethal force-short-of-war', in Fritz Allhoff, Nicholas G. Evans, and Adam Henschke (eds), Routledge Handbook of Ethics and War: Just War Theory in the Twenty-First Century (New York, NY: Routledge, 2013), pp. 63-75 (p. 68).

${ }^{28}$ Emery and Brunstetter, 'Restricting the preventive use of force', p. 258.

${ }^{29}$ Daniel R. Brunstetter, 'Wading knee-deep into the Rubicon: Escalation and the morality of limited strikes', Ethics \& International Affairs, 34:2 (2020), pp. 161-73 (p. 162).

${ }^{30}$ Daniel Brunstetter, 'Jus ad vim: A rejoinder to Helen Frowe', Ethics \& International Affairs, 30:1 (2016), pp. 131-6 (p. 132).

${ }^{31}$ Brunstetter, 'Jus ad vim', p. 135.

${ }^{32}$ Ford, 'Jus ad vim and the just use of lethal force-short-of-war', p. 67.
} 
criminal suspects 'in areas that, under the current dichotomous framework [war or law enforcement], generally are characterised as non-conflict zones' ${ }^{33}$ Or, according to some moral theorists, jus ad vim might simply be redundant because Just War theory can already deal adequately with different magnitudes of force. ${ }^{34}$ If so, it would make no analytical difference if a jus ad vim morality were introduced for evaluating drone violence.

In any event, the more important issue for present purposes is the strength of the vim concept itself as a basis for making moral judgements about political violence. The concept rests critically upon the notion that, when it comes to categorising force, size (and size alone) matters. Vim is force 'short of' war; it differs from war because it involves a lesser quantum of violence. Thus, the difference appears only to be one of degree rather than kind. Although jus ad vim advocates are admirably keen to plug what they see as a gap in the principled governance of violence in the world, they have arguably not completed the conceptual groundwork that is necessary to open up space for normative analysis. Despite their insistence that vim is not war (because a jus ad vim framework makes no sense otherwise), those advocates have not addressed adequately the challenge of determining whether a given instance of state violence counts as vim or war. As yet, there is no underlying 'falling short' (of war) theory addressing, for example, what the essential difference is between, on the one hand, war on a small scale or of short duration and, on the other hand, force 'short of war. So, while ever the concept of vim remains vague in general, it is difficult to proceed confidently towards moral judgement on the basis that drone violence in particular is vim.

Promoters of a jus ad vim framework have had much to say about what vim's characteristics are from time to time - how much violence is involved, where it occurs, who resorts to it, and why - but they have not offered a compelling definition of its nature. Rather, vim has tended only to be (under-)described in negative and relative terms. As non-war violence it tends, moreover, to be compared only to 'full-scale', 'widespread', and 'large-scale' war. ${ }^{35}$ And so, when vim is discussed in this way, a distinction ends up being drawn not between 'war' and 'force short of war' but rather between 'large-scale war' and 'force short of large-scale war'. The trouble, then, with trying to equate the amount of violence with its essence is that vim becomes radically susceptible to conceptual contestation, and the original problem returns: determining which (if any) moral framework is applicable to 'grey' violence. For example, violence that seemed small scale to the stronger side in a political confrontation (the self-styled deliverer of $v \mathrm{im}$ ) could plausibly seem large scale to the weaker side (the self-styled recipient of bellum).

If the vim concept is thus too weak a foundation upon which to base moral judgements about drone strikes, only war and law enforcement remain as concepts of legitimate state violence. In which case, outside of war, any lethal violence not wielded for a law enforcement purpose could reasonably be presumed by default to be unjustly homicidal. After all, when thinking morally about violence, the human right to life is the starting point and it can sometimes be the endpoint too (in the sense that the permissibility or excusability of killing is never established). As Michael Walzer has put it, the problem in moral theory is not to describe how immunity is gained, but how it is lost. We are all immune to start with; our right not to be attacked is a feature of normal human relationships. ${ }^{36}$ Accordingly, without a law enforcement or vim concept available to support it, non-war drone violence (signature strikes against suspected terrorists outside

\footnotetext{
${ }^{33}$ Ben Jones and John M. Parrish, 'Drones and dirty hands', in Fisk and Ramos (eds), Preventive Force, pp. 283-312 (p. 299).

${ }^{34}$ C. A. J. Coady, Morality and Political Violence (Cambridge, UK: Cambridge University Press, 2008), p. 7; Helen Frowe, 'On the redundancy of jus ad vim: A response to Daniel Brunstetter and Megan Braun', Ethics \& International Affairs, 30:1 (2016), pp. 117-29 (p. 117).

${ }^{35}$ See Brunstetter and Braun, 'From jus ad bellum to jus ad vim'.

${ }^{36}$ Michael Walzer, Just and Unjust Wars (4 ${ }^{\text {th }}$ edn, New York, NY: Basic Books, 2006), p. 145. See also Mary Ellen O'Connell, 'The law on lethal force begins with the right to life', Journal on the Use of Force and International Law, 3:2 (2016), pp. 205-09.
} 
conflict zones) could be condemned for involving attacks against persons whose immunity to attack remains in place. One possible explanation that then arises is that drone violence of this kind is essentially terroristic.

\section{Drone strikes as terroristic violence}

Most drone strikes conducted by the CIA, a civilian agency of the US government, have taken place in Pakistan's FATA region. ${ }^{37}$ Here, according to numerous reports, the population at large was collectively terrified during periods (occurring between 2004 and 2017) when armed drones were a constant overhead presence. ${ }^{38}$ The maintaining of the threat of aerial violence was intended to have a continuously suppressing effect on the activities of 'militants' in that part of the world, but this effect was inevitably also oppressive of everyone else who was made to experience mortal fear from one day to the next. Ordinary people were impelled to think that they could suddenly become a victim - seemingly anywhere and at any time - and sometimes the fear of this eventuality was so great as to cause psychological harm. ${ }^{39}$

The fact of a widespread feeling of terror in FATA has occasioned several authors to conceptualise US drone use there as an example of terroristic violence. In contrast to war, law enforcement, and vim, the 'terrorism' concept traditionally comes with its own built-in judgement framework. To describe violence in this way is also to condemn it as being necessarily unjust. So, when confronted with the moral problem of 'grey' drone violence apparently going on in the world unchecked, a frequent response among some scholars has been to frame this phenomenon as 'terrorism'. A 2018 issue of Critical Studies on Terrorism carried a collection of papers that all 'situate drone-inflicted violence within the wider context of state terrorism' ${ }^{40}$ According to Afxentis Afxentiou, 'drone warfare should be investigated as a form of terrorist violence', ${ }^{41}$ and for Laurie Calhoun it is a 'fact' that 'drone campaigns terrorise entire communities of people, just as did the plane attacks of 11 September 2001' ${ }^{2}$ Along similar lines, arguments have been advanced that the use of armed drones follows a 'logic of terrorizing a population', ${ }^{43}$ that drones 'may be considered a form of terrorism' to the extent that they 'produce terror in civilian populations', ${ }^{44}$ that drones 'inflict mass terror upon entire

\footnotetext{
${ }^{37}$ Bureau of Investigative Journalism, 'Drone Strikes in Pakistan', Bureau of Investigative Journalism (February 2020), available at: \{https://www.thebureauinvestigates.com/projects/drone-war/Pakistan\} accessed 24 March 2021.

${ }^{38}$ Jessica Purkiss and Jack Serle, 'US Drones Appear to Have Returned to Pakistan', Bureau of Investigative Journalism (6 March 2017), available at: \{https://www.thebureauinvestigates.com/stories/2017-03-06/us-drones-return-to-pakistan\} accessed 24 March 2021. Reports include: Conor Friedersdorf, “Every person is afraid of the drones”: The strikes' effect on life in Pakistan', The Atlantic (25 September 2012), available at: \{https://www.theatlantic.com/international/archive/ 2012/09/every-person-is-afraid-of-the-drones-the-strikes-effect-on-life-in-pakistan/262814/\} accessed 19 March 2021; International Human Rights and Conflict Resolution Clinic at Stanford Law School and Global Justice Clinic at NYU School of Law, 'Living Under Drones: Death, Injury, and Trauma to Civilians From US Drone Practices in Pakistan' (September 2012), available at: \{http://www.livingunderdrones.org/\} accessed 24 March 2021; Human Rights Clinic at Columbia Law School and the Center for Civilians in Conflict, 'The Civilian Impact of Drones: Unexamined Costs, Unanswered Questions' (11 September 2012), available at: \{https://civiliansinconflict.org/publications/research/civilianimpact-drones-unexamined-costs-unanswered-questions/\} accessed 27 August 2021.

${ }^{39}$ Taylor Owen, 'Drones don't just kill: Their psychological effects are creating enemies', The Globe and Mail (13 March 2013), available at: \{https:/www.theglobeandmail.com/opinion/drones-dont-just-kill-their-psychological-effects-are-creatingenemies/article9707992/\} accessed 9 March 2021.

${ }^{40}$ Marina Espinoza and Afxentis Afxentiou, 'Editors' introduction: Drones and state terrorism', Critical Studies on Terrorism, 11:2 (2018), pp. 295-300 (p. 295).

${ }^{41}$ Afxentis Afxentiou, 'A history of drones: Moral(e) bombing and state terrorism', Critical Studies on Terrorism, 11:2 (2018), pp. 301-20 (p. 305).

${ }^{42}$ Calhoun, 'Totalitarian tendencies in drone strikes by states', p. 370.

${ }^{43}$ Shaw, Predator Empire, p. 136.

${ }^{44}$ Steven P. Lee, 'Human rights and drone "warfare”, Peace Review, 27:4 (2015), pp. 432-9 (p. 436).
} 
populations', ${ }^{45}$ and that the US drone programme is 'a contemporary manifestation' of 'imperial state terrorism'. ${ }^{46}$

Arguably, there is a problem with claims of this kind. Although drone violence can indeed have a generally terrifying effect where it occurs, it cannot properly be condemned as terroristic violence without evidence of deliberate targeting of civilians. In other words, for analytical purposes a distinction should be drawn: the fact of civilians feeling threatened by violence does not equate to the moral wrong of deliberately threatening with violence people who are understood to be civilians. As the latter is not the only possible cause of the former, the terrifying use of drones is potentially not an essentially terroristic act. Here it must be acknowledged that the meaning of 'terrorism' remains highly contested and, perhaps, has in some instances become 'too ideologically freighted to have any analytic value'. ${ }^{47}$ Even so, in the careful assessment of a drone-using state's violence, it seems reasonable to proceed as non-ideologically as possible by using an object-focused definition of terrorism. Such a definition, unlike an agent-focused definition, ${ }^{48}$ can encompass non-state and state agents of violence. And it has the advantage also of emphasising that feature that is morally most distinctive about terrorism: the employing of violence, for a political purpose, against civilian (or non-combatant) targets. ${ }^{49}$

In the case of US drone violence that has occurred extraterritorially, outside war zones, and without a law enforcement purpose, conceptualising and judging it as terroristic is made difficult by the sparseness of the empirical record. Little, if any, evidence of deliberate targeting of civilians has come to light, if indeed it has been going on at all. There have been some reports of so-called 'double tap' (or 'second strike') drone attacks occurring, which appear to involve the killing of people who are seen coming to the rescue of victims of the first strike. ${ }^{50}$ If true, this killing has probably been done on the assumption that the rescuers too are members of the same group being targeted by the US government. But it seems implausible to frame these secondary targets as dangerous (non-innocent) allies of the individuals who were struck first, especially in the moment when a drone's mounted camera shows them providing medical assistance rather than busily posing a threat to the United States. At least in theory, then, 'double tap' drone strikes in non-war contexts are open to be condemned as instances of terroristic violence.

In the absence of a wrongful intention, violence might still be properly described as terroristic if innocents are harmed by a violent actor's recklessness. David Rodin has characterised the latter as 'the culpable bringing about of unintentional evil consequences (or the risk thereof) that are in fact unreasonable and unjustified in the circumstances'. ${ }^{51}$ And, with regard to war contexts, he has argued that this issue arises particularly in the case of 'aerial bombardment against targets within or adjacent to civilian populations which is almost certain to generate noncombatant casualties'. ${ }^{52}$ On one occasion, in early 2010, a US drone was reportedly used to kill an al-Qaeda commander in Miram Shah, a small town in FATA's North Waziristan

\footnotetext{
${ }^{45}$ Grégoire Chamayou, Drone Theory, trans. Janet Lloyd (London, UK: Penguin, 2015), p. 45.

${ }^{46}$ Ruth Blakeley, 'Drones, state terrorism and international law', Critical Studies on Terrorism, 11:2 (2018), pp. 321-41 (p. 323).

${ }^{47}$ Samuel Scheffler, 'Is terrorism morally distinctive?', The Journal of Political Philosophy, 14:1 (2006), pp. 1-17 (p. 1).

${ }^{48}$ See Ruth Blakely, 'State terrorism in the social sciences: Theories, methods and concepts', in Richard Jackson, Eamon Murphy, and Scott Poynting (eds), Contemporary State Terrorism Theory and Practice (London, UK: Routledge, 2010), pp. 12-27.

${ }^{49}$ Mitja Sardoč, 'Re-thinking violence: An interview with C. A. J. Coady', Critical Studies on Terrorism, 12:4 (2019), pp. 735-47 (p. 739).

${ }^{50}$ Zulfiqar Ali, 'Two US drone strikes kill 6 militants in North Waziristan: Officials', The Express Tribune (19 August 2012), available at: \{https://tribune.com.pk/story/424117/us-drone-strike-kills-four-militants-in-pakistan-officials\} accessed 29 March 2021; Glenn Greenwald, 'US drone strikes target rescuers in Pakistan - and the West stays silent', The Guardian (20 August 2012), available at: \{https://www.theguardian.com/commentisfree/2012/aug/20/us-drones-strikes-target-rescuers-pakistan\} accessed 24 March 2021; Amnesty International, 'Will I Be Next?', p. 20.

${ }^{51}$ David Rodin, 'Terrorism without intention', Ethics, 114:4 (2004), pp. 752-71 (p. 764).

${ }^{52}$ Rodin, 'Terrorism without intention', p. 762.
} 
district, ${ }^{53}$ and this could reasonably be described as a 'recklessly terroristic' drone strike in the sense that it almost certainly endangered many other people in the town. However, as with allegedly intentional 'double tap' drone strikes, there is a paucity of evidence that the US government has been generally reckless by routinely conducting drone strikes in heavily populated urban areas. In any event, the notion of 'reckless' terrorism is not as well established in moral theory as is the straightforwardly intentional kind. The latter, arguably, is of greater moral significance (and perhaps it is the only proper notion of terrorism) because it involves bringing a 'guilty mind' to bear upon one's violence.

On the whole, then, it is difficult to conceptualise and condemn the US government's wider counterterrorist drone programme as terroristic in nature. In contrast to the view of some early theorists of air power who claimed that this should be directed against an enemy state's civilian population (to terrorise them into submission), ${ }^{54}$ the US government's drone violence in FATA and elsewhere has proceeded according to a stated determination to avoid targeting innocents. ${ }^{55}$ Although this alone does not prove the absence of any terroristic intent, it is nevertheless worth noting that scholarly denunciations of US drone violence as 'terrorism' have thus far not been founded on evidence of intentional targeting of civilians. Some scholars have instead argued that, because the effects (on civilians) of drone strikes resemble the effects of terroristic applications of air power that undoubtedly occurred in the past, contemporary drone violence amounts to terrorism too. Yet, even if it is a historical 'fact' that 'organised terror has always been a component of regimes of aerial control', ${ }^{6}$ it does not follow that terrorism must be the essence of any or all drone violence today. Unless or until evidence of intentional wrongdoing emerges, it is fairer to presume that the US government has not in fact wilfully engaged in a sustained enterprise - extending from one drone strike to the next - of wielding terroristic violence.

\section{Drone strikes as imperialistic violence}

If there are insufficient grounds to conceptualise drone violence outside war zones as terrorism, another concept worth considering as a basis for condemnation is imperialism. In much of the academic literature on armed drones, it has often been implied that contemporary US drone violence is wrong in the same way that 'air policing' in colonial history was wrong. Here, the 'newness' (and potential legitimacy) of drone violence tends to be disputed by claims about historical continuity and, for a number of authors, historicising such violence is a way of criticising it. This can be quite a persuasive approach given that so many violent acts from the past were either wrong at the time or would not be morally acceptable today. It is an approach mostly encountered in postcolonial and critical geography literature that situates the use of armed drones in a lineage of colonial technologies of pacification'. ${ }^{57}$ And this situating usually involves the drawing of 'parallels' between the rationales and technologies underpinning drone strikes and those underpinning the use of air power by European imperial powers in the early twentieth century. ${ }^{58}$

According to Priya Satia, the use of armed drones exhibits 'critical continuities with earlier [colonial] uses of air power,, 59 and Campbell Munro has argued that drones 'undoubtedly

\footnotetext{
${ }^{53}$ Joby Warrick and Peter Finn, 'CIA Director says secret attacks in Pakistan have hobbled al-Qaeda', Washington Post (18 March 2010), p. A01.

${ }^{54}$ See Afxentiou, 'A history of drones', p. 311.

${ }^{55}$ See John Brennan, 'The Ethics and Efficacy of the President's Counterterrorism Strategy', Wilson Center (30 April 2012), available at: $\{$ https://www.wilsoncenter.org/event/the-efficacy-and-ethics-us-counterterrorism-strategy $\}$ accessed 23 March 2021.

${ }^{56}$ Espinoza and Afxentiou, 'Editors' introduction', p. 297.

${ }^{57}$ Akhter, 'The proliferation of peripheries', p. 64.

${ }^{58}$ Oliver Kearns, 'Secrecy and absence in the residue of covert drone strikes', Political Geography, 57:1 (2017), pp. 13-23 (p. 18).

${ }^{59}$ Priya Satia, 'Drones: A history from the British Middle East', Humanity, 5:1 (2014), pp. 1-31 (p. 1).
} 
mark a further evolution in imperial air policing' by functioning as 'a means to exercise asymmetric imperial violence'. ${ }^{60}$ Similarly, other authors have claimed that the deployment of armed drones 'resembles' colonial war, ${ }^{61}$ that the drone 'reactivates a colonial form of power', ${ }^{62}$ and that the US drone programme for the targeted killing of terror suspects 'builds directly on the British experience of imperial policing through air power'. ${ }^{63}$ Such arguments find circumstantial support in the fact that virtually all drone violence to date has occurred in many of the same places that were previously the scene of imperial European air policing. Derek Gregory has noted, for example, 'numerous dispiriting parallels' between contemporary US drone campaigns and British aerial counterinsurgency efforts in the 1920s along the Northwest Frontier (later part of Pakistan) and in Mesopotamia (later Iraq). ${ }^{64}$ Other 'wild spaces of the imperial periphery' once subjected to 'imperial control from above, ${ }^{65}$ where armed drones have also since appeared, include Afghanistan, Libya, Palestine (now part of Israel), Somaliland (now part of Somalia), Syria, and Yemen.

After the end of the First World War, the victorious European powers found that their imperial governance responsibilities had increased, but the material means of sustaining all of them had declined. Pre-war imperial garrisons around the world needed to be maintained, but the 1919 Treaty of Versailles required Britain and France to govern also their post-Ottoman 'mandate' territories in the Middle East. It was Britain's Royal Air Force (RAF) that introduced to the world the practice of using air power to maintain civil order. This was done mainly because it seemed to be a cheaper means of maintaining the 'imperial peace' than the older, army-based method of sending punitive expeditions to quell local unrest. ${ }^{66}$

It is less certain, however, that the US government too has lately been using air power for an imperial purpose in the sense that this has been part of a 'process of establishing and maintaining an empire'. ${ }^{67}$ There is perhaps a broader debate to be had about whether the United States is an empire, ${ }^{68}$ but the narrower issue in this article is whether US drone violence outside war zones is imperialistic. Arguably, this kind of non-war violence, unlike colonial air policing of old, cannot be conceptualised (and thereby condemned) as imperialistic. Although the 'empire' concept, like 'terrorism', remains a subject of definitional debate, ${ }^{69}$ one of the most frequently cited formulations is Michael Doyle's: that empire is 'a relationship ... in which one state controls the effective political sovereignty of another political society'. ${ }^{70}$ Historically, such control is what critically enables imperial acquisition (of territory or other resources) and it manifests in 'civilisatory' rule by the imperial power. For present purposes, then, a fair theoretical assumption is that

\footnotetext{
${ }^{60}$ Campbell Munro, 'The entangled sovereignties of air police: Mapping the boundary of the international and the imperial', Global Jurist, 15:2 (2015), pp. 117-38 (p. 127), emphasis removed.

${ }^{61}$ Samuel Moyn, 'Drones and imagination: A response to Paul Kahn', European Journal of International Law, 24:1 (2013), pp. 227-33 (p. 227).

${ }^{62}$ Derek Gregory, 'Dirty dancing: Drones and death in the borderlands', in Lisa Parks and Caren Kaplan (eds), Life in the Age of Drone Warfare (Durham, NC and London, UK: Duke University Press, 2017), pp. $25-58$ (p. 45).

${ }^{63}$ Blakeley, 'Drones, state terrorism and international law', p. 327.

${ }^{64}$ Derek Gregory, 'From a view to a kill: Drones and late modern war', Theory, Culture \& Society, 28:7-8 (2011), pp. 188215 (p. 189).

${ }^{65}$ Munro, 'The entangled sovereignties of air police', p. 125.

${ }^{66}$ See Michael Paris, 'Air power and imperial defence, 1880-1919', Journal of Contemporary History, 24:2 (1989), pp. 20925; David E. Omissi, Air Power and Colonial Control: The Royal Air Force, 1919-1939 (Manchester, UK: Manchester University Press, 1990).

${ }^{67}$ Michael W. Doyle, Empires (Ithaca, NY: Cornell University Press, 1986), p. 19.

${ }^{68}$ See Desmond King, 'When an empire is not an empire: The US case', Government and Opposition, 41:2 (2006), pp. 16396; Alfred W. McCoy, Policing America's Empire: The United States, the Philippines, and the Rise of the Surveillance State (Madison, OH: University of Wisconsin Press, 2009); David Harvey, The New Imperialism (Oxford, UK: Oxford University Press, 2003).

${ }^{69}$ Dominic Alessio and Wesley Renfro, 'Empire?', European Journal of American Studies, 15:2 (2020), pp. 1-22 (p. 13).

${ }^{70}$ Doyle, Empires, p. 45.
} 
imperialistic violence is essentially an instrument of exploitative acquisition and transformative administration.

In the 1920s, for example, British imperial control of Mesopotamia was both acquisitive and administrative in nature. The colonial administration, led by the RAF and reliant upon air power, was geared towards the extraction of local oil wealth. ${ }^{71}$ And, according to Peter Lieb, Britain's aerial operations there were influenced by a view of Arabs and Kurds as 'semi-civilised' peoples who had remained 'savages' while under Ottoman imperial, but who could yet be civilised by superior colonial rulers. ${ }^{72}$ Satia has described aerial 'bombardment' in British-ruled Iraq as 'a permanent method of colonial administration'. ${ }^{73}$ Thomas Hippler has observed that RAF air power there had 'established a genuine government from the sky. ${ }^{74}$ And meanwhile, in British-ruled Sudan, Governor-General Sir John Maffey had reportedly described British airstrikes as a 'swift agent of government. ${ }^{75}$

By contrast, US drone violence against suspected terrorists in Pakistan, Somalia, and Yemen has been instrumental neither for resource acquisition nor local administration. The use of armed drones in these places has undoubtedly had a fearsome and coercive effect, but it has not risen to the level of 'control' (over 'another political society') ${ }^{76}$ such as would warrant conceptualising such violence as imperialistic. ${ }^{77}$ US drone violence evidences little by way of an imperial impulse to conquer, occupy, colonise, and plunder these territories over which drones fly, and it does not support any broader US attempt at on-the-ground rule there. ${ }^{78}$ On the contrary, armed drones seem perfectly suited to avoiding those things while the US government instead restricts itself to the mere management of terrorism risks emerging along its 'terror frontier'.

The taking of the latter approach also suggests strongly that the US government's drone violence is not instrumental in an imperial mission civilisatrice. Although the United States might well see itself as 'a premier guardian of civilisation', perceiving terrorists as 'threats to a civilized way of life, ${ }^{79}$ US drones do not practically support any effort to 'civilise' the Pakistani, Somali, or Yemeni 'wildernesses' from which those threats supposedly emanate. The drones are not, in other words, instruments to force 'progress' in those places towards a 'superior' condition of being. Rather, US drone violence does not aim for the eventual improvement of local life but only for the constant containment of individualised dangerousness and the suppression of security risks to a manageable level. Whereas once the American idea of a frontier imagined 'a spatially expansive progression of [European] civilization into the wilderness of the American continent', ${ }^{80}$

\footnotetext{
${ }^{71}$ Oliver Davis, 'Theorising the advent of weaponized drones as techniques of domestic paramilitary policing', Security Dialogue, 50:4 (2019), pp. 344-60 (p. 348).

${ }^{72}$ Peter Lieb, 'Suppressing insurgencies in comparison: The Germans in the Ukraine, 1918, and the British in Mesopotamia, 1920', Small Wars \& Insurgencies, 23:4 (2012), pp. 627-47 (pp. 634-5).

${ }^{73}$ Priya Satia, Spies in Arabia: The Great War and the Cultural Foundation of Britain's Covert Empire in the Middle East (Oxford, UK: Oxford University Press, 2008), p. 240.

${ }^{74}$ Thomas Hippler, Governing from the Skies, A Global History of Aerial Bombing, trans. David Fernbach (London, UK: Verso, 2017), pp. 68-9.

${ }^{75}$ David Killingray, “'A swift agent of government”: Air power in British Colonial Africa, 1916-1939', Journal of African History, 25:4 (1984), pp. 429-44 (p. 431).

${ }^{76}$ Doyle, Empires, p. 45

${ }^{77}$ Article 42 of the 1907 Hague Regulations states that a territory is considered 'occupied' when 'it is actually placed under the authority of the hostile army' and the 'occupation extends only to the territory where such authority has been established and can be exercised'. Here, the exercise of 'effective control' of territory is understood to be essential because this substantiates the notion of 'authority'. See Tristan Ferraro, 'Determining the beginning and end of an occupation under International Humanitarian Law', International Review of the Red Cross, 94:885 (2012), pp. 133-63 (pp. 134, 140).

${ }^{78}$ According to Derek Gregory, US drone violence is thus distinguishable from the use of armed drones in the occupied Palestinian territories where the state of Israel exercises effective control: Gregory, 'Dirty dancing', p. 41.

${ }^{79}$ Shaw, Predator Empire, p. 126.

${ }^{80}$ Sonja Schillings, Enemies of All Humankind: Fictions of Legitimate Violence (Hanover, NH: Dartmouth College Press, 2017), p. 127.
} 
the 'terror frontier' territories where US drones fly today do not seem destined to be brought into the fold of 'civilisation'. Instead, there appears to be an acceptance by the US government that these are places to be merely policed - remotely, violently, and perhaps in perpetuity.

\section{Quasi-imperialism and US drone violence}

If drone violence of the kind described above is not genuinely imperialistic, it may yet be conceptualised and criticised for being almost (quasi) imperialistic. Some authors have hinted at this, offering suggestions (laced with paradox) that the constant overhead presence of armed drones amounts to 'aerial occupation', 81 or 'nonterritorial occupation', 82 or even a 'distinctly ambiguous' form of occupation. ${ }^{83}$ A more straightforward approach, however, is to acknowledge that the exclusive use of armed drones by a foreign power really involves non-occupation. This reality can then be addressed as a defining characteristic of quasi-imperialistic violence as well as a source of its moral problems.

In the study of International Relations, the term 'quasi-imperial' has previously been applied by Martin Shaw. Writing in 2002, he used it while trying to employ the 'empire' concept in an analytical (value-neutral) way and to encourage scholars to be 'sharper about what is really imperial and what is not'. ${ }^{84}$ Shaw described some larger, non-Western states in the modern, postcolonial world as 'reconstitutions of historic pre-European or European empires' ${ }^{85}$ In places like China, India, Indonesia, Russia, and Turkey, he observed national politics dominated by 'quasi-imperial relations of rule' involving 'internal colonialism' and the violent domination of one nation by another within state borders. ${ }^{86}$ Pakistan too could thus be described as exercising quasi-imperial rule over its FATA region, where formerly the ruling was done imperially. As was the case during the time of British colonial rule, when the 1901 Frontier Crimes Regulation (FCR) was introduced, the FATA remains to this day an exceptional legal space where (as a legacy of the FCR) human rights are not nearly as protected as they are in the rest of Pakistan. ${ }^{87}$ Inside what Madiha Tahir has called the FATA 'containment zone, ${ }^{88}$ any violence enacted by the Pakistani military is, on Shaw's definition, quasi-imperialistic. However, US (drone) violence there is not, because the power dynamic this introduces is international rather than internal in character.

Or, pace Shaw, political violence could instead be conceptualised as quasi-imperialistic in an alternative sense: when it is wielded in furtherance of a 'temporary' episode of liberal imperialism. The latter is the kind of quasi-imperialism implied by Michael Ignatieff's idea of 'empire lite'. Here, US rule of foreign territories is understood to be less than genuinely imperial because it is not intended to be permanent. Rather, its purported aim is to foster democratic nation-building in other countries. In his 2003 book Empire Lite, Ignatieff observed of the 'Afghans', for example, that 'their best hope for freedom lies in a temporary experience of [US] imperial rule'. ${ }^{89}$ Through US-sponsored nation-building, that is, his idea was that the state of Afghanistan would soon become 'strong enough to keep al-Qaeda from returning'. ${ }^{90}$ At the time, the US government

\footnotetext{
${ }^{81}$ John R. Emery and Daniel R. Brunstetter, 'Drones as aerial occupation', Peace Review, 27:4 (2015), pp. 424-31 (p. 424); Campbell A. O. Munro, 'Mapping the vertical battlespace: Towards a legal cartography of aerial sovereignty', London Review of International Law, 2:2 (2014), pp. 233-61 (p. 238).

${ }^{82}$ Shaw, Predator Empire, p. 256.

${ }^{83}$ Gregory, 'Dirty dancing', p. 30.

${ }^{84}$ Martin Shaw, 'Post-imperial and quasi-imperial: State and empire in the global era', Millennium: Journal of International Studies, 31:2 (2002), pp. 327-36 (p. 329).

${ }^{85}$ Ibid., p. 333.

${ }^{86}$ Ibid., p. 334.

${ }^{87}$ Ian Shaw and Majed Akhter, 'The unbearable humanness of drone warfare in FATA, Pakistan', Antipode, 44:4 (2012), pp. 1490-509 (p. 1498).

${ }^{88}$ Madiha Tahir, 'The containment zone', in Parks and Kaplan (eds), Life in the Age of Drone Warfare, pp. $220-40$.

${ }^{89}$ Michael Ignatieff, Empire Lite (London, UK: Vintage, 2003), p. 107.

${ }^{90}$ Ignatieff, Empire Lite, p. 79.
} 
was heavily engaged in a ground-based counterinsurgency effort in Afghanistan, with some air support provided by armed drones. By contrast, in Pakistan, Somalia, and Yemen, where drone violence (often used exclusively) has ostensibly served only a counterterrorism purpose, the US government has not pursued the 'empire lite' (nation-building) version of quasi-imperialism either.

For present purposes, then, the term 'quasi-imperialism' needs to be understood differently: as a transnational political exercise in thin domination motivated by an open-ended commitment to anti-responsibility. In comparison with the use of piloted aircraft making short sorties, the longendurance capacity of armed drones is much more conducive to achieving a continuous disruption of emerging and perceived threats. Drone violence that is quasi-imperialistic in this sense is the violence of risk-management rather than rule, and it essentially avoids the responsibility (for the welfare of the dominated) that is required (morally and legally) to be assumed by an occupying power.

In the broader context of counterterrorism, some authors have already identified a US preference for aiming only to managing risks rather than to solve problems. ${ }^{91}$ And the armed drone in particular, as an instrument for killing suspected terrorists, has appeared to be well suited to the inherently indefinite task of terrorism 'management'. ${ }^{92}$ For other authors, drone violence of this kind is best captured by the notion of 'policing'. Here, though, that notion tends to be employed not in the narrow (liberal) sense of fighting crime but instead to describe a process of ordering. ${ }^{93}$ On this understanding, the use of armed drones is certainly not policing as a community service, much less policing by popular consent. It is rather undertaken solely for the benefit of the drone-using state, as it seeks to minimise risks to its national security. And meanwhile, from the perspective of local populations who are 'policed', the practice of such violence carries the potential for privation (not provision) of personal security.

Maintaining internal security, ensuring public safety and providing basic services are among the obligations the United States would assume if it acted imperially in Pakistan, Somalia, and Yemen. ${ }^{94}$ But by only employing armed drones in a quasi-imperialistic way, the US government has managed to avoid the responsibilities of occupation (as well as the associated financial costs and political risks). If, by contrast, it donned the mantle of the state and laid claim to the monopoly of legitimate force within the foreign territories where US drones fly, this would run the risk of triggering the law enforcement paradigm of state violence. And, in turn, the ethical expectations arising in that paradigm would require the wielding of (drone) violence to be much more restrained.

This is not to suggest, however, that quasi-imperialistic drone violence can truly escape any moral judgement at all. The fact of non-occupation does not affect the fundamental presumption that every person (qua potential victim) has a right to life, so such violence remains open to be judged according to rights-based principles that are applicable by default. Even if the US government's use of armed drones against suspected terrorists located outside war zones does not amount to violent law enforcement, the principles of necessity, proportionality, and discrimination remain available for the purpose of moral assessment. Accordingly, as the next section shows, such drone use can be judged as morally unacceptable for three reasons that relate to the essential open-endedness of quasi-imperialistic violence: it is temporally unnecessary,

\footnotetext{
${ }^{91}$ See Yee-Kuang Heng, 'The "transformation of war" debate: Through the looking glass of Ulrich Beck's World Risk Society', International Relations, 20:1 (2006), pp. 69-91 (p. 70); Elke Schwarz, Death Machines: The Ethics of Violent Technologies (Manchester, UK: Manchester University Press, 2018), p. 4.

${ }^{92}$ Agius, 'Ordering without bordering', pp. 370-1; Alex Danchev, 'Bug splat: The art of the drone', International Affairs, 92:3 (2016), pp. 703-13 (p. 706).

${ }^{93}$ Mark Neocleous, 'Air power as police power', Environment and Planning D: Society and Space, 31:4 (2013), pp. 578-93; Munro, 'The entangled sovereignties of air police'.

${ }^{94}$ The fulfilment of these occupier obligations does not render imperialism per se morally acceptable. See Rahul Rao, 'The empire writes back (to Michael Ignatieff)', Millennium: Journal of International Studies, 33:1 (2004), pp. 145-66 (p. 161).
} 
excessively harmful over time, and eventually indiscriminate as between the 'dangerous' and the innocent.

\section{The injustice of quasi-imperialistic drone violence}

The right to life includes the right not to be killed arbitrarily. When killing is done for a public purpose (on a state's behalf), it is not 'arbitrary', in the sense that it is not done as a matter of private (personal) whim. Beyond that, though, there needs to be a sound reason for taking a human life, and the most basic reason is that it is somehow 'necessary' to do so. In a war context, the relevant principle is military necessity, and this can generally be satisfied if violence is expected to achieve an advantage or reduce a risk. The use of an armed drone could be deemed militarily necessary because friendly ground troops are under fire and in need of air support. A necessity principle applies in law enforcement contexts too, although here it has a more restricted meaning: for example, a police officer may only use a lethal weapon against a criminal suspect if there is no other available way to save the life of a person who is in immediate danger. Outside of these two established paradigms of legitimate state violence, it is more difficult to establish the necessity of killing someone.

Indeed, in attempting to legitimise its quasi-imperialistic drone violence against suspected terrorists, the US government has been able to approach this task only by relying heavily on a critical but dubious claim about temporal necessity (the lack of any later opportunity to respond) and the 'imminence' of a threat. In 2011, White House advisor John Brennan argued that 'a more flexible understanding of "imminence" may be appropriate when dealing with terrorist groups' ${ }^{95}$ And, the following year, US Attorney General Eric Holder claimed that the imminence of a terrorist attack depends on 'considerations of the relevant window of opportunity to act, the possible harm that missing the window would cause to civilians, and the likelihood of heading off future disastrous attacks'. ${ }^{96}$ This official effort to stretch the ordinary meaning of imminence was roundly criticised (sometimes to the point of ridicule) for being so obviously wrong from a conceptual standpoint. ${ }^{97}$ Rosa Brooks observed, for example, that the Obama administration's definition of imminence 'does not require actual imminence', thus making the concept 'as loose, ill defined, and self-serving as might be imagined'. 98

The moral problem with conducting a drone strike well before a terrorist attack is genuinely imminent (about to happen) is that it restricts the scope for non-violent response options to be brought to bear, and thus it makes the occurrence of state violence more likely and more frequent. Such violence, when conducted so far in advance of a threat materialising, can appear to be essentially preventive, or even 'merely "preferential"', 99 rather than necessary. And so there is room to conclude that the US government's quasi-imperialistic drone violence is arbitrarily abusive of the right to life in the sense that it occurs without a sufficiently good reason (from a temporal perspective) to kill a targeted individual now.

\footnotetext{
${ }^{95}$ John O. Brennan, 'Strengthening our Security by Adhering to our Values and Laws', The White House (16 September 2011), available at: \{https://obamawhitehouse.archives.gov/the-press-office/2011/09/16/remarks-john-o-brennan-strengthening-our-security-adhering-our-values-an\} accessed 24 March 2021.

${ }^{96}$ Eric Holder, 'Attorney General Eric Holder Speaks at Northwestern University School of Law', US Department of Justice (5 March 2012), available at: \{https://www.justice.gov/opa/speech/attorney-general-eric-holder-speaks-northwestern-university-school-law\} accessed 31 March 2021.

${ }^{97}$ See Dennis R. Schmidt and Luca Trenta, 'Changes in the law of self-defence? Drones, imminence, and international norm dynamics', Journal on the Use of Force and International Law, 5:2 (2018), pp. 201-45 (p. 202); Aiden Warren and Ingvild Bode, 'Altering the playing field: The U.S. redefinition of the use-of-force', Contemporary Security Policy, 36:2 (2015), pp. 174-99 (p. 186).

${ }^{98}$ Rosa Brooks, 'Drones and cognitive dissonance', in Peter L. Bergen and Daniel Rothenberg (eds), Drone Wars: Transforming Conflict, Law, and Policy (New York, NY: Cambridge University Press, 2015), pp. 230-52 (p. 244 ), original emphasis.

${ }^{99}$ Neil C. Renic, 'A gardener's vision: UAVs and the dehumanisation of violence', Survival, 60:6 (2018), pp. 57-72 (p. 64).
} 
When the necessity of state violence is doubtful, it follows that the security benefit (threat reduction) to be derived from it might only be slight or negligible. It takes little foreseeable harm, then, to outweigh the moral value of that benefit and render the violence disproportionate (excessive). Empirically, the exact balance of benefits and harms derived from drone strikes outside war zones has been difficult to determine, especially over the long term. ${ }^{100}$ Even so, several factors appear to reduce the security benefit to be gained by US signature strikes. Firstly, most of those killed in such strikes are reportedly not the most influential terrorists (commanders) but rather are low-level ones. ${ }^{101}$ Secondly, the use of 'signatures' (an assemblage of probable indices of dangerousness) still leaves plenty of room for mistakes and misunderstandings, such that too few strikes might be killing people who in fact pose a threat to the United States. ${ }^{102}$ Thirdly, the intelligence-led character of drone strikes against suspected terrorists creates perverse incentives for other actors in the foreign territories where targeting occurs. That is, local governments might secure forceful US assistance only by exaggerating the internal threat they face from insurgent ('terrorist') groups ${ }^{103}$ or individual CIA informants might fabricate allegations and thereby encourage US drone strikes against individuals in furtherance of personal feuds. ${ }^{104}$ And fourthly, even if a drone strike kills someone who really poses a threat, the very killing of that person precludes the gaining of a further benefit: actionable intelligence on terrorist operations they were planning with others who are still alive. ${ }^{105}$

If, in combination, these factors make quasi-imperialistic drone violence an enterprise that brings few or dubious benefits, they have the moral effect also of making it harder to excuse any harm that drones incidentally inflict upon innocents in the vicinity of targeted individuals. Moreover, the longer such violence persists, the more likely it is to become disproportionate (or more disproportionate). This is an especially serious moral risk given that the operational logic of quasi-imperialistic drone strikes against suspected terrorists located in remote areas is to continuously disrupt their plans. To be achieving this effect on an ongoing basis is also to be continually running the risk that the imperfect, signature-based strike process will cause the wrong people to die.

Armed drones already have the powerful potential to be a persistent presence in places where airspace is uncontested, and technological developments might increase this potential in the future. ${ }^{106}$ In addition, to the extent that US drone strikes fuel the anti-US terrorist threat, they have the capacity to generate ever more targets in 'a seemingly inescapable loop'. ${ }^{107}$ Morally, because violence cannot always be a good thing, the harm that results from it can only begin to be legitimised by trading it off temporarily against an expected benefit. Thus, the indefinite exposing of people in a foreign territory to the risk of harm (intended or unintended) presents a problem of temporal disproportionality. In this way too, then, quasi-imperialistic drone violence can unjustly imperil the human right to life.

When a campaign of drone violence involves the indefinite endangerment of innocents, it becomes 'eventually' indiscriminate. This is so even if, from one strike to the next, there is an

\footnotetext{
${ }^{100}$ Hazelton, 'Drone strikes and grand strategy', pp. 71-2; Patrick B. Johnston and Anoop K. Sarbahi, 'The impact of US drone strikes on terrorism in Pakistan', International Studies Quarterly, 60:2 (2016), pp. 203-19 (p. 203).

${ }^{101}$ In a media report on signature strikes in Yemen, an anonymous US official reasoned: 'they might not be big names now ... but these were the guys that would have been future leaders': Eric Schmitt, 'Embassies open, but Yemen stays on terror watch', New York Times (12 August 2013), p. A1.

${ }^{102}$ Chamayou, Drone Theory, p. 49; Renic, 'A gardener's vision', p. 267.

${ }^{103}$ James Igoe Walsh, The Effectiveness of Drone Strikes in Counterinsurgency and Counterterrorism Campaigns (Carlisle, PA: Strategic Studies Institute, 2013), pp. 4-5.

${ }^{104}$ Hillel Ofek, 'The tortured logic of Obama's drone war', The New Atlantis, spring (2010), pp. 35-44 (p. 37); Azhar Masood, 'Pakistani tribesmen settle scores through US drones', Arab News (23 May 2011), available at: \{www.arabnews. com/node/378426\} accessed 4 March 2021.

${ }^{105}$ Audrey Kurth Cronin, 'The strategic implications of targeted drone strikes for US global counterterrorism', in David Cortright, Rachel Fairhurst, and Kirsten Wall (eds), Drones and the Future of Armed Conflict (Chicago, IL and London, UK: University of Chicago Press, 2015), pp. 99-120 (p. 119).

${ }^{106}$ Clive Blount, 'Useful for the next hundred years? Maintaining the future utility of airpower', The RUSI Journal, 163:3 (2018), pp. 44-51 (p. 46).

${ }^{107}$ Jameel Jaffer, The Drone Memos: Targeted Killing, Secrecy and the Law (New York, NY: The New Press, 2016), p. 20.
} 
intention only to kill the non-innocent (suspected terrorists). The US government has repeatedly issued assurances that its drone strikes are conducted with great care to avoid 'civilian' casualties, ${ }^{108}$ and in so doing it has highlighted the 'precision' capability of an armed drone. ${ }^{109}$ It is undoubtedly the case that, unlike piloted aircraft, drones can loiter above a prospective target for hours 'waiting for the ideal moment to strike'. ${ }^{110}$ However, innocents too are nevertheless sometimes killed unintentionally by exposure to the wider effects (blast waves and flying shrapnel) of 'pinpoint' missile strikes. Or, the death of an innocent who suddenly appears on the scene might result from the drone operator's inability to steer away a descending missile in time (because of the delay of several seconds as a signal bounces between a drone, a satellite and the control station).

In the context of US drone violence that aims to be continually disruptive (of emergent 'terrorist' threats), such deaths are not a moral problem because of any wrongful intention. Rather, they are a problem because the US government must know, after long experience, that innocents will almost certainly keep getting killed in its signature strikes. Strictly speaking, these killings are accidental in the sense of being unintended and undesired, and yet their occurrence is also the result of sustained and systematic endangerment. Eventually, and because quasi-imperialism essentially involves an open-ended commitment to violent risk management, a pattern sets in of 'routinely knowing' that drone strikes in aggregate will kill innocents. ${ }^{111}$ And, once the morally undesirable outcome of a certain kind of violent action has become so highly predictable, it is arguably wrong to keep performing that action in the same way without trying to improve it.

The knowledge that innocents keep dying in signature strikes establishes a duty to take greater and greater precautions in the face of a highly foreseeable risk, but the US government has arguably neglected this duty by making too little effort to increase the degree to which its drone violence is discriminate in practice. When it comes to judging the permissibility of state violence, Rodin has advocated using the concept of negligence (rather than intention) in order to focus attention on 'what constitutes an appropriate standard of care' in the use of force. ${ }^{12}$ And, in accordance with this alternative process of moral reasoning, C. A. J. Coady has suggested that 'a number of drone attacks deployed by the United States in the war on terror ... have been insufficiently concerned with the non-combatant deaths they cause collaterally'. ${ }^{113}$

Such concern could manifest in a serious effort to count and report the number of innocents killed and to be ever striving to improve targeting practices. Against this, in 2019 the Trump administration stopped disclosing estimates of how many suspected terrorists and innocent bystanders are killed in US drone strikes outside war zones. ${ }^{114}$ However, in the practice of quasi-imperialistic drone violence, the problem of insufficient care extends further than this. By using armed drones in remote areas, the US government arranges for itself to be largely incapable of morally improving this violence. Careful, on-the-ground evaluations of distant drone strikes are deemed infeasible, so there is limited scope to learn lessons (about the accuracy of targeting) that could immediately be applied (for the benefit of innocents) to the conduct of future strikes.

It is arguably not enough, then, for a US president to set as 'the highest standard' a requirement of 'near-certainty that no civilians will be killed or injured' before any drone strike is

\footnotetext{
${ }^{108}$ In 2014 President Obama stated his administration's commitment to carry out counterterrorist drone strikes 'only where . . . there is near certainty of no civilian casualties'. Barack Obama, 'Remarks by the President at the United States Military Academy Commencement Ceremony', The White House (28 May 2014), available at: \{https://obamawhitehouse. archives.gov/the-press-office/2014/05/28/remarks-president-united-states-military-academy-commencement-ceremony\} accessed 24 March 2021.

${ }^{109}$ In 2012 John Brennan claimed that the 'surgical precision' of drone strikes gave the US government the ability to kill 'an al-Qaida terrorist' with 'laser-like focus'. Brennan, 'The Ethics and Efficacy of the President's Counterterrorism Strategy'.

${ }^{110}$ Daniel Byman, 'Why drones work: The case for Washington's weapon of choice', Foreign Affairs, July/August (2013), pp. 32-43 (p. 34).

${ }^{111}$ James DeShaw Rae, 'Drones and a culture of death', Peace Review, 27:4 (2015), pp. 477-83 (p. 478).

${ }^{112}$ Rodin, 'Terrorism without intention', p. 765.

${ }^{113}$ Sardoč, 'Re-thinking violence', p. 741.

${ }^{114}$ Savage and Schmitt, 'Biden quietly limits drone strikes away from war zones', p. A12.
} 
taken. ${ }^{115}$ Rather, because a campaign of quasi-imperialistic violence is essentially an open-ended one, there needs also to be a sincere and unrelenting effort to get ever nearer to actual certainty. To carry on running the risk of making the same mistakes, without trying constantly to reduce the number of mistakes, is effectively to accept an unreduced risk to innocents. Such a negligent disposition, towards violence that must eventually be indiscriminate, is destined to involve violations of the human right to life.

\section{Conclusion}

A new administration in the White House presents an opportunity for a reset of US drone policy. In using armed drones against suspected terrorists located far away and outside war zones, the US government has struggled to claim successfully that drone strikes count as war, and it has been unwilling to accept the restrictions on violence that apply in the peacetime law enforcement paradigm. So, it has sought instead to claim that another ('grey') paradigm of legitimate state violence exists in between the established paradigms war and law enforcement. Unless or until this notion is generally accepted, however, the greyness of some drone violence will keep generating concern that unjust killings are able to occur with impunity because there is no recourse to traditional principles of restraint. Gaining some governance purchase on violence of this kind is an increasingly urgent task as more states acquire armed drones and look to the example set by the US government on how to use them. To this end, it is important first to establish a plausible conceptualisation of nonwar drone violence, which can then serve as a basis for moral judgement.

To conceptualise such violence as vim, with a view to judging it according to a jus ad vim framework, is unhelpful because the vim concept remains under-described and radically vague. As such, its use might only compound the problem of categorical greyness. However, two betterunderstood concepts - terrorism and imperialism - cannot plausibly be applied to US drone violence outside war zones either. According to an object-focused definition of terrorism, a campaign of drone strikes is not essentially terroristic if it does not involve the deliberate targeting of innocents. And nor is drone violence imperialistic if it is not wielded by a foreign power imposing imperial rule, imperially acquiring resources and assuming imperial responsibilities.

In Pakistan, Somalia, and Yemen, the US use of signature strikes against suspected terrorists is better conceptualised as quasi-imperialistic in nature. Foreign-armed drones have only thinly dominated the populations of these parts of the world, and the drone-using state has not been acting there out of a sense of responsibility to those populations. Rather, the United States has been engaging in an ongoing exercise of merely and aerially policing terrorist risks to its national security. Conceptualised in this way, US drone use can nevertheless be assessed as a source of injustice, even if it has the immediate appearance of being less harmful than the heavy domination that characterises imperialistic violence. The essential open-endedness of quasi-imperialistic drone violence still carries the potential for abuse of the right to life when it is temporally unnecessary, excessively harmful over time, and eventually indiscriminate. While ever violence of this kind endures, it is morally unacceptable, so it ought to be avoided.

Acknowledgements. Research for this article was supported by funding from the European Research Council (ERC) under the European Union's Horizon 2020 research and innovation programme (Grant No. 771082). For providing valuable feedback on earlier versions of this article, the author is grateful to Caroline Holmqvist, Nina Kollars, and three anonymous EJIS reviewers.

Christian Enemark is Professor of International Relations at the University of Southampton, United Kingdom.

${ }^{115}$ Obama, 'Remarks by the President at the National Defense University', emphasis added.

Cite this article: Enemark, C. 2022. The enduring problem of 'grey' drone violence. European Journal of International Security 7, 304-321. https://doi.org/10.1017/eis.2021.24 